For consideration in: Biological Invasions

\title{
Removal of livestock alters native plant and invasive mammal communities in a dry grassland-shrubland ecosystem
}

Amy L. Whitehead · Andrea E. Byrom • Richard I. Clayton · Roger P. Pech

A. L. Whitehead · A. E. Byrom · R. I. Clayton · R. P. Pech

Landcare Research, PO Box 69040, Lincoln 7640, New Zealand

e-mail: byroma@landcareresearch.co.nz

Phone: +64 33219629 Fax: +64 33219998

R. P. Pech

Joint Graduate School in Biodiversity and Biosecurity, School of Biological Sciences, University of Auckland, New Zealand

Running head: Destocking alters invaded communities 


\begin{abstract}
The impacts of domesticated herbivores on ecosystems that did not evolve with mammalian grazing can profoundly influence community composition and trophic interactions. Also, such impacts can occur over long time frames by altering successional vegetation trajectories. Removal of domesticated herbivores to protect native biota can therefore lead to unexpected consequences at multiple trophic levels for native and non-native species. In the eastern South Island of New Zealand large areas of seral grassland-shrubland have had livestock (sheep and cattle) removed following changes in land tenure. The longterm (>10 years) outcomes for these communities are complex and difficult to predict: land may return to a native-dominated woody plant community or be invaded by exotic plants and mammals. We quantified direct and indirect effects of livestock removal on this ecosystem by comparing plant and invasive mammal communities at sites where grazing by livestock ceased c.10-35 years ago (conservation sites) with paired sites where pastoralism has continued to the present (pastoral sites). There was higher total native plant richness and reduced richness of exotic plants on conservation sites compared with pastoral sites. Further, there were differences in the use of conservation and pastoral sites by invasive mammals: rabbits and hedgehogs favoured sites grazed by livestock whereas house mice, brushtail possums and hares favoured conservation sites. Changes in the relative abundance of invasive mammal species after removal of domesticated livestock may compromise positive outcomes for conservation in successional plant communities with no evolutionary history of mammalian grazing.
\end{abstract}

Keywords Biotic invasions · Exotic plant · Invasive mammal · Livestock removal $\cdot$ Native plant richness $\cdot$ Pastoralism 


\section{Introduction}

The effects of domesticated herbivores on ecosystems that did not evolve with mammalian grazing can be profoundly different from those on communities and ecosystems that evolved with herbivores (Cingolani et al. 2005; Diaz et al. 2007; Lunt et al. 2007). Removal of domesticated herbivores may protect native biota but can lead to unexpected consequences at more than one trophic level for native and non-native species (Elmhagen and Rushton 2007). Also, while the effects of domesticated herbivores can be profound in the short term (Courchamp and Caut 2006), they can also take decades to play out, for example by influencing successional vegetation trajectories (Walker et al. 2009).

In ecosystems where domesticated herbivores have been introduced, grazing by livestock can alter community composition by reducing native plant richness (Walker and Lee 2002; Kimball and Schiffman 2003; Haarmeyer et al. 2010), an effect that is often reversed with removal of livestock (Allcock and Hik 2004; Souter and Milne 2009). Also, grazing typically leads to short vegetation communities (Diaz et al. 2007; May et al. 2009), often with low shrub recruitment and decreased structural complexity (Lee et al. 2010). Such effects on community composition differ from ecosystems that evolved with grazing by large herbivores (Skaer et al. 2013), particularly in highly productive systems where grazing may increase plant diversity (Cingolani et al. 2005; Bakker et al. 2006).

Grazing can also have indirect effects on native plant richness by altering exotic vegetation (Kimball and Schiffman 2003; Grosholz 2010). Exotic plants may in turn negatively affect native vegetation communities through altered abiotic conditions (e.g. increased shading or altered soil chemistry) or competitive exclusion (Mack et al. 2000; Norton et al. 2006; Sage et al. 2009). For example, the presence of hawkweeds (Hieracium and Pilosella genera) is commonly thought to signal a highly degraded ecosystem (Mark and Dickinson 2003; Walker et al. 2005; Weigelt et al. 2007), particularly in low-productivity sites (Fensham et al. 2011). Hawkweeds deplete soil nutrients and restrict the regeneration of 
native seedlings (Norton et al. 2006), and some hawkweed species can alter ecosystem processes through changes in soil chemistry (Scott et al. 2001; Day and Buckley 2013).

Livestock grazing also has an influence on associated mammal fauna, both native (Kutt and Gordon 2012) and introduced (Dodd et al. 2011). In turn, this can affect species diversity and ecosystem function (Legge et al. 2011) through bottom-up effects (Scherber et al. 2010a, b), with some evidence that increased diversity of vegetation is associated with generalist herbivores (Fabian et al. 2012). Removal of livestock should therefore have profound effects on invaded ecosystems (Rose and Frampton 2007; Firn et al. 2010) at more than one trophic level (Mack et al. 2000).

Management of such ecosystems is best informed by an evidence-based approach (Skaer et al. 2013) to help conservation managers identify clearly the potential bottom-up and top-down mechanisms driving changes in plant and animal communities when livestock are removed (Denyer et al. 2010). Few studies, however, have quantified the long-term (> 10 years) impacts of removal of livestock and subsequent changes in native and exotic vegetation while simultaneously quantifying the responses of invasive mammals. Multi-factorial experiments could provide the relevant data but, in their absence, potential drivers of change can be inferred from management experiments based on alternative land uses.

In the eastern South Island of New Zealand, large areas of pastoral land are being retired from farming through a review process that assesses the ecological and economic value of government-owned land leased to pastoralists (Walker et al. 2008). Former pastoral land has a long history of anthropogenic disturbance including repeated burning, first by Polynesians and later by European pastoralists (McGlone and Wilmshurst 1999). These ecosystems have no evolutionary history of mammalian grazing, but recent $(<150$ years $)$ pastoral use has resulted in extensive grazing by sheep (Ovis aries) and cattle (Bos taurus), often on highly modified grassland that has been fertilised and sown with exotic grasses. Further modification of these ecosystems occurred with the introduction of invasive mammals in the late 19th century including herbivores (European rabbits Oryctolagus cuniculus, 
Bennett's wallabies Macropus rufogriseus, and brown hares Lepus europaeus), an insectivore (the European hedgehog Erinaceus europaeus), and omnivores (house mice Mus musculus, ship rats Rattus rattus, and brushtail possums Trichosurus vulpecula). Of these species, rabbits in particular are known to favour grazing the short-stature pastures resulting from pastoralism (Norbury and Reddiex 2005), whereas wallabies, possums and hares tend to have mixed diets of shrub, grass and forbs (Cowan 2005; Norbury and Flux 2005; Warburton 2005).

Ecosystems used for pastoralism are under-represented in conservation reserves worldwide and consequently their protection is becoming increasingly important (Rogers et al. 2005). In New Zealand, when grazing and other disturbances are reduced in newlycreated conservation areas, grasslands with early-successional assemblages are postulated to change to species-rich woody communities over time, with this directional change reversing declines in indigenous plant dominance that occurred under continuous pastoralism (Walker et al. 2009).

In this paper we quantify direct and indirect effects of livestock removal on plant and invasive mammal communities in a grass-shrubland ecosystem by comparing sites where grazing by livestock ceased 10-35 years ago (conservation sites) with adjacent areas where pastoralism has continued to the present (pastoral sites). We used a comparative approach, assessing differences in vegetation and invasive mammal communities across fenceline boundaries, to test the following predictions.

Prediction 1. A change in land tenure from pastoral to conservation status will result in different invasive mammal communities on either side of the fence:

(a) herbivores with specialist requirements for short-grass habitat (rabbits) will have greater presence on pastoral sites compared with conservation sites;

(b) generalist herbivores and omnivores (possums, hares and rodents) will have greater presence in plant communities with greater plant species richness, i.e. on conservation sites compared with pastoral sites. 
Prediction 2. On conservation sites, the removal of livestock will result in:

(a) increased species richness of native plants (e.g. via enhanced recruitment of plant species previously suppressed by grazing); and

(b) increased dominance of native shrubs in the plant community (due to enhanced recruitment of perennial woody species).

Prediction 3. On pastoral sites, continued grazing by livestock will result in:

(a) dominance of exotic, grazing-tolerant grasses and forbs in the plant community;

(b) lower species richness of native plants.

We tested these predictions at two scales: the scale at which non-native herbivores, including livestock, are managed ( hectares), and at a microhabitat scale $\left(\sim \mathrm{m}^{2}\right)$ where the processes of selective herbivory and plant-plant competition are likely to be important.

\section{Methods}

Study areas

Study areas were located in the central South Island of New Zealand (latitudinal range $43.3^{\circ} \mathrm{S}$ to $\left.44.4^{\circ} \mathrm{S}\right)$ (Table 1) in subalpine zones (1000 $\mathrm{m}$ a.s.1.), where former pastoral lands are typically mixtures of native and non-native woody shrubland species (Bellingham 1998; Coomes et al. 2002; Tate et al. 2003). When ungrazed, there is a tendency towards increased cover of woody vegetation through secondary succession (Walker et al. 2009). Our sites had low productivity and relatively low rainfall compared with other parts of New Zealand (Walker and Lee 2005).

We chose areas with a well-maintained stock fence separating sites grazed by sheep or cattle (pastoral sites) and destocked sites (conservation sites). Conservation sites had been used for pastoralism from early European settlement in the mid-19th century until at least 
1980. All sites were within an elevational range suitable for establishment of shrublands (Partridge et al. 1991).

Study design

Paired pastoral and conservation sites were selected within four areas: Coach Stream (1 pair); Boundary Hill (2 pairs); Freehold Creek (3 pairs); and Mount Nimrod (2 pairs) (total 8 sites; Fig. 1 and Table 1). The minimum distance between pairs of sites within an area was $200 \mathrm{~m}$. By using paired pastoral and conservation sites we were able to control for climate, aspect, soil type, local seed bank and accessibility by small-sized invasive mammals. Also we aimed to avoid recently burned or fertilised pastoral sites to minimise possible influences on successional trajectories, but parts of two properties, at Freehold Creek and Mt Nimrod, had received sporadic applications of fertiliser prior to our study. All surveys were conducted in early 2009 (mid- to late austral summer). Further details on field sites are available in Online Resource 1.

Field methods

On each site, we established grids of size $100 \times 140 \mathrm{~m}$, with $10 \mathrm{~m}$ between grid points on lines spaced $20 \mathrm{~m}$ apart (Fig. 1). The 140-m side of each grid was aligned parallel with the fence, with one grid placed on the pastoral side and one on the conservation side. Grids were offset from the fence by a minimum of $5 \mathrm{~m}$ to avoid edge effects. Data were collected on plant species' presence and structure, and on the relative abundance of all introduced mammals (livestock and invasive mammals).

Each grid point $(n=24)$ of the outer rectangle on both pastoral and conservation sites contained one mouse and one rat snap-back trap baited with peanut butter and covered to prevent small birds from entering. Traps were left for 3 nights, checked daily and rebaited if 
rodents were captured. We placed footprint tracking tunnels to detect small mammals (King and Edgar 1977) at 20-m spacing at every second internal grid point $(n=24)$. Alternating with each tracking tunnel (also at 20-m spacing) were 24 chew cards (Sweetapple and Nugent 2011). Chew cards and tracking tunnels were used to determine activity patterns of rabbits, hares, hedgehogs, wallabies, rats, mice and possums. Counts of latrines for rabbits (Virgós et al. 2003), and individual faecal pellets for hares and livestock, were conducted along 1210 $\times 2 \mathrm{~m}$ belt transects within each site (Fig. 1).

At each grid point, percentage cover was estimated in a $2 \times 2 \mathrm{~m}$ plot for all woody plant species occupying $>5 \%$ of the plot, in $10 \%$ intervals down from $100 \%$. We also recorded the percentage cover of all vascular plant species, plant litter, rock and bare ground in a $0.5 \times 0.5 \mathrm{~m}$ quadrat nested randomly within the $2 \times 2 \mathrm{~m}$ shrub-cover plot. We defined ground species as all plants $<0.3 \mathrm{~m}$ high. To quantify species richness, we recorded all species present in each plot.

\section{Statistical analyses}

Indirect effects of livestock removal on the invasive mammal community

Data from chew cards, tracking tunnels, snap traps and pellet counts were pooled to test the prediction that a change in land tenure from pastoral to conservation status resulted in a change in invasive mammal communities on either side of the fence at the management scale (Prediction 1). This method also confirmed the exclusion of livestock from conservation sites. The relative activity of each species at the site level was estimated by summing the number of monitoring devices and transects with animal sign within a given site. These data were analysed using non-metric multidimensional scaling (NMDS) to assess visually differences between sites, with rare species down-weighted. NMDS is a robust unconstrained ordination technique commonly used in ecological studies (Kenkel and Orloci 1986). We also conducted 
a non-parametric MANOVA to test for animal community differences between sites, where species permutations were constrained within sites. The non-parametric MANOVA was performed using ANODIS from the "vegan" library (Oksanen et al. 2010) in R (R Development Core Team 2009), a function for the analysis and partitioning of distance matrices that is analogous to parametric MANOVA (Anderson 2001).

Effects of livestock removal on the vegetation community

We evaluated the potential effects of the change in land tenure from pastoral to conservation status on vegetation community composition (Predictions 2 and 3) at two spatial scales: (1) the impacts of livestock removal on exotic and native plant species richness at the site level, i.e. management-scale impacts, and (2) how native plant species richness was affected by local conditions at the plot and quadrat level, i.e. microhabitat scale. To assess these effects, we structured our analyses to account for the nested study design (quadrats nested within plots, nested within sites, and pairs of sites nested within areas). Vegetation data from quadrats and plots were pooled to determine the total number of species present in the immediate vicinity of each grid point and, for ease of interpretation, these are subsequently referred to as plots. We then estimated the relative abundance of individual species at each site using the number of occupied points. Data were analysed using NMDS and nonparametric MANOVA to detect differences in the vegetation community between sites.

We also assessed differences in species richness between pastoral and conservation sites at the management scale. Mean plot values of total, native and exotic species richness were calculated for each site, and assessed using one-way ANOVA, treating site as a random effect to remove inherent differences between sites. Preliminary analyses indicated that the inclusion of "area" as a random effect did not explain any additional variation so it was not included in the models. We also used the plot data in a similar way to assess differences in the richness and percent cover of shrub, exotic herb and exotic grass species. We controlled for 
multiple tests using the false discovery rate procedure (Verhoeven et al. 2005), a powerful alternative to the Bonferroni correction that seeks to minimize both type I and type II errors, with the allowed proportion of false positives set at 0.05 .

We used two sets of hierarchical generalised linear mixed-effects models, each of which modelled either the total richness of native plant species or richness of native ground species on the 1152 plots. The first set of models (site-level, or management-scale, models) tested the effects of livestock removal on total native and native ground species richness, as well as possible effects due to observed changes in the invasive mammal community. To test the mechanisms by which livestock removal might change local conditions and impact native plant species richness, we developed a second set of models (quadrat-level, or microhabitat, models) that included quadrat-level variables likely to be affected by site conditions: the cover of shrubs, exotic grasses, native tussocks, hawkweeds, litter, rock and bare ground. All models were fitted using a Poisson distribution for count data (O’Hara and Kotze 2010), with predictor variables standardised prior to analysis to improve the interpretability of the regression coefficients (Schielzeth 2010). Site was included as a random effect.

\section{Results}

Indirect effects of livestock removal on the invasive mammal community

Two domestic and seven invasive mammal species were recorded across the eight sites (Fig. 2a, b). The mammal community differed between sites, separated along Axis 1 of the NMDS ordination $\left(F_{7,8}=1.73, P=0.077\right)$. Livestock were separated from other mammals along Axis 2, with significant differences in community composition identified between pastoral and conservation sites when individual site differences were taken into account $\left(F_{1,14}=6.95, P<\right.$ 0.001). Field observations confirmed livestock were present exclusively on pastoral sites. These sites were typically associated with higher abundances of rabbits (Prediction 1a) and 
hedgehogs, whereas hares, possums and mice were predominant at conservation sites

(Prediction 1b). Wallabies and rats were locally abundant at the Mt Nimrod sites but were not observed elsewhere.

Effects of livestock removal on the vegetation community: management scale

A total of 244 vascular plant species were identified across the eight sites (Online Resource

1). Axis 1 of the NMDS ordination explained differences in vegetation community composition between sites (Fig. $2 \mathrm{c} ; F_{7,8}=2.83, P<0.001$ ). We also observed significant differences in the vegetation community between pastoral and conservation sites along Axis 2 when individual site differences were taken into account $\left(F_{1,14}=1.66, P<0.001\right)$. However, there was no consistent trend in the direction or magnitude of the compositional change.

There was no significant difference in mean species richness between sites in pastoral or conservation tenure (Table 2). However, conservation sites had significantly higher native species richness and lower exotic species richness than pastoral sites (Predictions 2a and 3). Total and native shrub richness did not differ between pastoral and conservation sites. Although $75 \%$ of conservation sites had higher total and native shrub cover, this trend was not significant (Prediction 2b). There was also no difference in the number of exotic shrub species or exotic shrub cover between pastoral and conservation sites. Native tussocks did not vary significantly in species richness or cover between pastoral and conservation sites.

Pastoral sites had significantly more exotic grass and forb species than conservation sites (Prediction 3a). Four invasive hawkweed species and 13 exotic grass species were recorded across the eight sites (Online Resource 1). However, there was no significant difference in hawkweed species richness or cover between pastoral and conservation sites (Table 2). Pilosella officinarum was the most abundant hawkweed species across all sites with a mean cover score of $12.5 \pm 0.6 \%$, followed by Hieracium praealtum $(4.0 \pm 0.2 \%)$ and H. lepidulum $(2.9 \pm 0.3 \%)$. P. aurantiaca was rarely observed, covering less than $0.1 \%$ of 
the three plots in which it occurred. Co-occurrence of hawkweed species was common within plots. We observed differences in the distribution of hawkweed species between properties, with P. officinarum and H. lepidulum dominant at Boundary Stream sites, and P. officinarum and H. praealtum most common at Freehold Creek sites. Coach Stream and Mount Nimrod sites had few occurrences of the four hawkweed species.

Livestock removal resulted in significantly higher total native plant richness at conservation sites but no difference in native ground richness (Prediction 2a; total native richness: $Z=2.174, P=0.030$; native ground richness: $Z=1.639, P=0.101)$. Native plant richness was not correlated with the invasive mammal community (total native richness: $Z=0.027, P=0.978$; native ground richness: $Z=-0.033, P=0.973$ ); nor did we observe any interaction between land tenure and the invasive mammal community with respect to native plant richness (total native richness: $Z=-0.741, P=0.457$; native ground richness: $Z=-$ $0.596, P=0.551)$.

Effects of livestock removal on the vegetation community: microhabitat scale

There were significant interactions between plot-level variables and land tenure with respect to native species richness (Fig. 3a). The total richness of native species was strongly influenced by exotic grass cover, cover of exotic forbs, and the proportional cover of rock. Exotic grasses reduced total native richness, with significantly greater influence in plots at pastoral sites (Prediction 3b; $Z=-4.129, P<0.001$ ), but high cover of hawkweed was positively correlated with total native richness in conservation plots $(Z=3.132, P=0.002)$. The presence of high rock cover was associated with high total native richness in pastoral plots but low total native richness in conservation plots $(Z=-4.803, P<0.001)$. Total native plant richness increased when plots contained lower percentages of bare ground $(Z=-1.868$, $P=0.062)$ but this effect did not vary significantly between tenures $(Z=-0.786, P=0.432)$. 
The remaining predictors (tussock cover, shrub cover and litter) did not have a significant impact on total native richness in plots.

Similar patterns were found to drive the richness of native ground species (Fig. 3b), with additional significant interactions for shrubs and tussocks. High cover of shrubs and exotic grasses (Prediction 3) was associated with low native ground richness, and these effects were strongest in pastoral plots (exotic grass: $Z=5.728, P<0.001$; shrubs: $Z=2.268$, $P=0.023)$. In comparison, both tussock and hawkweed cover were negatively correlated with native ground richness in pastoral plots but showed a positive association in conservation plots (tussock: $Z=2.565, P=0.010$; hawkweed: $Z=2.849, P=0.004$ ). Rock cover was positively correlated with native ground richness in pastoral plots but negatively correlated in conservation plots $(Z=-3.650, P<0.001)$. The presence of bare ground was associated with reduced richness of native ground species $(Z=-2.394, P=0.017)$ but the effects did not differ significantly between tenure types $(Z=-0.455, P=0.649)$. The presence of litter did not have a significant impact on native ground richness.

\section{Discussion}

Removal of livestock grazing is a major ecosystem-level perturbation that often occurs with a change in land tenure, and it can have particularly profound effects in ecosystems that did not evolve with grazing mammals. While livestock removal is not the only perturbation that can occur with tenure changes (fire, fertiliser and irrigation regimes may also be altered), we chose to focus on this change because it is perhaps the most ubiquitous perturbation that directly affects successional processes in dryland ecosystems in New Zealand (Walker et al. 2009) and elsewhere (Cingolani et al. 2005). Few studies have investigated the effects of such a change on both the associated vegetation and invasive mammal communities. There was support for the prediction that removal of livestock would increase species richness of native vegetation on conservation sites. In addition, there was support for the prediction that reduced 
richness of native plant species would be associated with high cover of exotic plant species on pastoral sites. We were also able to identify in broad terms, differences in activity patterns in the invasive mammal community on pastoral and conservation sites.

Indirect effects of livestock removal on the invasive mammal community

Pastoral and conservation sites were favoured by different suites of invasive mammals. Because we did not conduct manipulative experiments, we cannot determine whether the observed patterns are driven from the bottom up (mammals simply respond to conditions created by plant-plant processes), top down (mammals engineer suitable habitat), or a combination of both, but on the basis of our observations we can make some inference. Exclusion of large herbivores is often observed to cause structural changes in vegetation cover, which in turn influences the distribution of small mammal species (Smit et al. 2001). Some small mammals (e.g. mice) require complex habitat structure to provide cover from predators (Smit et al. 2001; Arthur et al. 2004; Norbury et al. 2013) whereas others (e.g. rabbits) may benefit from the presence of short grass associated with grazing livestock (Denyer et al. 2010). We observed this in our study. We also observed that although rabbits were able to move freely between pastoral and conservation sites, they were unable to graze at the same intensity as livestock on the conservation sites, resulting in successional vegetation change. Both these observations imply a bottom-up dynamic. The presence of mice, rats and possums can have negative impacts through predation on native fauna (Innes et al. 1999; Angel et al. 2008) and on seeds (Wilson and Lee 2010). In addition, all three species may have indirect effects on vegetation succession (Dungan et al. 2002). Hedgehogs, which are ubiquitous in many New Zealand ecosystems (Jones and Sanders 2005), were associated with grazed pasture, presumably due to the abundance of their preferred invertebrate prey. 
Our observation that medium-term changes in the invasive mammal community with removal of livestock were associated with differences in composition of the plant community suggests that invasive mammals could also influence the outcomes of vegetation succession in other as-yet-unquantified ways, depending on the species involved. Endozoochory - the dispersal of viable seeds in the gut of an animal - may be an important factor affecting rates of spread of both native and exotic plants in New Zealand (Thorsen et al. 2009; Forsyth et al. 2010), and invasive mammals may be an important vector (Williams et al. 2000; Dungan et al. 2002). With recent changes from livestock grazing to conservation management across large areas of New Zealand's drylands (Walker et al. 2008), changes in seed dispersal rates resulting from changes in the abundance and composition of vector species may be an important influence on succession from grassland to shrubland (Young 2012), but such mechanisms need to be tested experimentally.

Livestock removal and native plant richness

The act of removing livestock for conservation purposes comes with an assumption that this will lead to a recovery in native plant richness. We observed higher total native plant richness and lower richness of exotic vegetation on conservation sites compared with pastoral sites. This is in contrast to observations from ecosystems that evolved with grazing (e.g. Skaer et al. 2013). However, we did not observe the same overall significant effect on each component of native vegetation, i.e. tussock (bunchgrass), shrub, or ground species. These findings are likely due to differences in the community composition among sites, with some conservation sites tending towards native shrub-dominated communities and others dominated by native tussocks. Removal of livestock leads to the recovery of dominant tussock species in talltussock grasslands, with a corresponding decline in native inter-tussock species in New Zealand (Rose and Platt 1992; Grove et al. 2002; Mark and Dickinson 2003) and elsewhere (Souter and Milne 2009). Similarly in short-tussock communities, removal of livestock can 
lead to the recovery of shrub and inter-tussock species (Grove et al. 2002). The lack of response by tussocks or shrubs in our study may have been determined by initial conditions: presence or absence of native tussock grasses at the time of livestock removal may be critical for post-pastoral retention or recovery (Walker and Lee 2002). It is also possible that the time frame of our observational study (up to 35 years after removal of livestock) was not long enough to detect a measurable response in tussock diversity and dominance, which is plausible given the longevity of New Zealand's slow-growing tussock species (Mark 1969).

Livestock removal and exotic plant richness

We observed lower exotic plant species richness on conservation sites than pastoral sites, as has been observed elsewhere in New Zealand (Walker et al. 2003; Rose and Frampton 2007;). There was no support for the widely-held view that removal of livestock can lead to dominance of exotic grasses, for example due to competitive exclusion (Walker 2000; Meurk et al. 2002; Rose et al. 2004; Amiaud et al. 2008). Our results also did not support the notion that exotic shrub species are more likely than natives to become established after livestock removal. However, we chose sites with a predominance of native shrubs, so initial conditions may have influenced the outcome of secondary succession.

Effects of exotic vegetation on native plant richness

Exotic grasses and forbs (particularly hawkweeds) influenced the richness of native vegetation found on both pastoral and conservation sites. Superficially, our results suggest that the presence of hawkweeds had a positive effect on native plant richness when livestock were removed (Fig. 3). However, hawkweed cover was on average similar between pastoral and conservation sites, so hawkweed cover per se did not appear to directly influence native species richness. A more complex interpretation is that hawkweeds have a strong effect on 
competitive processes operating among plant species and a change in grazing pressure must change substantially the strengths of competitive interactions among those species. This fits with the notion that the effects of hawkweeds in structuring biophysical processes are complex (Diaz et al. 2007; Meffin et al. 2010). For example, hawkweeds are likely to invade tall-tussock grasslands when grazing opens up interstitial gaps, while short tussock is likely to be invaded even in the absence of grazing by livestock (Diez et al. 2009).

While some studies suggest that hawkweeds may increase in abundance irrespective of grazing intensity (Meurk et al. 2002; Rose and Frampton 2007), others found they did not appear to be enhanced by grazing, nor did livestock removal prevent hawkweed invasion (Rose et al. 1995; Rose et al. 2004). One clear difference between those studies and ours is the longer time frame over which potential plant competitive interactions could have been operating since livestock removal. It is possible that hawkweed presence (or cover) has few long-term effects on structuring dryland ecosystems, but ideally this should be examined using experimental manipulations (e.g. Meffin et al. 2010), over a longer time frame, and in both nutrient-rich and nutrient-poor systems (Fensham et al. 2011).

\section{Limitations of our study}

In terms of study design, comparison of similar sites subject to historically different livestock management offered an approach that complements long-term monitoring or direct experimental manipulation. As with other cross-fence studies (Verrier and Kirkpatrick 2005; Yeaton and Flores 2009), the validity of our conclusions rests on the assumption that environmental conditions on either side of the fence (e.g. slope, aspect, rainfall and soil conditions) were similar. We are confident that this assumption is reasonable, because we deliberately chose paired sites with similar environmental conditions, and paired plots were a maximum of $20 \mathrm{~m}$ apart. In addition, when selecting sites we applied a stringent criterion that the fence must be fully operational as a barrier to livestock, thereby avoiding poor-quality 
fences. Also, we confirmed with relevant land managers that pastoral sites were stocked regularly and that conservation sites had been destocked.

It was more difficult to control for the effects of some other management practices often used on pastoral properties. Residual effects of earlier fertilisation might have altered successional trajectories at some of our pastoral sites. In principle, this might have modified changes in plant species richness due to altered grazing regimes (Cingolani et al. 2005). However, there is minimal difference between "enhanced" and background levels of soil fertility for infrequent, low levels of fertiliser application (MacKay and Lambert 2011), such as that at the Freehold Creek study area (Online Resource 1). Harris and Fan (1996) suggested that, for much of the high country pastoral land in New Zealand, the rate and frequency of fertiliser application has not been sufficient to maintain oversown forage grasses and legumes, which implies that the level of fertiliser typically applied to pastoral areas would not have had a major impact on competition between exotic grasses and native plants.

Cross-fence studies also rely on similar starting conditions (i.e. that compositional elements of the system were broadly similar at the time of grazing removal). While this is an acknowledged limitation of "space for time" studies, we made every effort to locate paired sites that had similar histories of anthropogenic disturbance prior to construction of the fence. In addition, the successional trajectory of a particular community or ecosystem may be strongly influenced by already-existing compositional elements. For example, our study areas were dominated by native shrub species, mostly mānuka (Leptospermum scoparium) and matagouri (Discaria toumatou), and therefore may have favoured establishment of native species and facilitated native species richness. Areas dominated by exotic woody shrubs may show different successional trajectories. For example, Sage et al. (2009) observed that exotic briar (Rosa rubiginosa) shrubs were often taller, with higher cover, densities and recruitment in the absence of grazing by sheep.

Conclusions 
Consistent with previous studies, our results demonstrated moderate to strong effects of grazing by livestock on vegetation communities in seral grassland-shrubland ecosystems in New Zealand, with an increase in native species richness over the 10-35 years since grazing ceased. In New Zealand, dry grass/shrubland landscapes are under-represented as legallyprotected conservation areas (Rogers et al. 2005), so they are important for conservation. We conclude that removal of livestock from these ecosystems can lead to native-dominated plant communities, although the successional trajectory taken by the system will likely be sitedependent and will be influenced by availability of seed banks for regeneration, local physiographic factors, site fertility, and the presence and dominance of non-native woody shrubs and grasses. A major finding of our study was that this positive outcome for conservation may be compromised by changes in the relative abundance of exotic mammal species that are known to contribute to declines in several species of native fauna.

We were able to assess the effect of herbivory by livestock in grassland-shrubland systems that did not evolve with grazing mammals essentially because we used livestock removal as a treatment. Our findings have highlighted a number of hypotheses about topdown and bottom-up processes in these ecosystems that require testing experimentally. The likely strong top-down effects of grazing in structuring competition among plant species lend themselves to experimental manipulations such as factorial removal of sheep, possums, rabbits and mice to untangle the magnitude of the effects of herbivory, and would be a fruitful avenue for future research. In addition, experimental manipulation of vegetation structure, and the mix of exotic and native shrubs, could be used to assess bottom-up effects on the composition of the invasive mammal community.

Acknowledgements C Jensen, R Carran, E Hayman, V Harrison and G Pech assisted with collection of field data. N Thornley from the New Zealand Department of Conservation (DOC) provided maps showing boundaries of properties transferred to the conservation 
estate. C Thomson and J Whitford helped with site selection. R Duncan helped with data analysis and interpretation. Access to sites was provided by H Inch, B and J Kirk, G Burrows and DOC. This work was greatly improved by discussions with S Walker, S Timmins, C Krebs, ARE Sinclair, A Kenney, and J Reardon. A Mark provided insightful comments on an earlier draft of the manuscript. This work was funded by the New Zealand Ministry of Building, Innovation and Employment's Science and Innovation Group, through core funding to Crown Research Institutes and funding for contracted projects C09X0505 and C09X0909.

\section{References}

Allcock KG, Hik DS (2004) Survival, growth, and escape from herbivory are determined by habitat and herbivore species for three Australian woodland plants. Oecologia 138:231-241. doi.org/10.1007/s00442-003-1420-3

Amiaud B, Touzard B, Bonis A, et al. (2008) After grazing exclusion, is there any modification of strategy for two guerrilla species: Elymus repens (L.) Gould and Agrostis stolonifera (L.)? Plant Ecol 197:107-117. doi.org/10.1007/s11258-007-9364-Z

Anderson MJ (2001) A new method for non-parametric multivariate analysis of variance. Aust Ecol 26:32-46. doi.org/10.1046/j.1442-9993.2001.01070.x

Angel A, Wanless RM, Cooper J (2008) Review of impacts of the introduced house mouse on islands in the Southern Ocean: are mice equivalent to rats? Biol Invas 11:1743-1754. doi.org/10.1007/s10530-008-9401-4

Arthur A, Pech R, Dickman C (2004) Habitat structure mediates the non lethal effects of predation on enclosed populations of house mice. J Anim Ecol 73:867-877. doi.org/10.1111/j.0021-8790.2004.00864.X

Bakker ES, Ritchie ME, Olff H, et al. (2006) Herbivore impact on grassland plant diversity depends on habitat productivity and herbivore size. Ecol Lett 9:780-788. doi.org/10.1111/j.1461-0248.2006.00925.x 
Bellingham PJ (1998) Shrub succession and invasibility in a New Zealand montane grassland. Aust J Ecol 23:562-573. doi.org/10.1111/j.1442-9993.1998.tb00766.x

Cingolani A, Noy-Meir I, Diaz S (2005) Grazing effects on rangeland diversity: a synthesis of contemporary models. Ecol Appl 15:757-773. doi.org/10.1890/03-5272

Coomes DA, Allen RB, Scott NA, et al. (2002) Designing systems to monitor carbon stocks in forests and shrublands. For Ecol Manage 164:89-108. doi.org/10.1016/S0378$\underline{1127(01) 00592-8}$

Courchamp F, Caut S (2006) Use of biological invasions and their control to study the dynamics of interacting populations. In: Cadotte M, McMahon S and Fukami T (eds) Conceptual ecology and invasion biology: reciprocal approaches to nature. Invasion Ecology 1. Springer, pp 243-269

Cowan PE (2005) Brushtail possum. In: King CM (ed) The handbook of new Zealand mammals, 2nd edn, Oxford University Press, Melbourne, Australia, pp 56-80

Day NJ, Buckley HL (2013) Twenty-five years of plant community dynamics and invasion in New Zealand tussock grasslands. Aust Ecol doi.org/10.1111/aec.12016

Denyer JL, Hartley SE, John EA (2010) Both bottom-up and top-down processes contribute to plant diversity maintenance in an edaphically heterogeneous ecosystem. J Ecol 98:498-508. doi.org/10.1111/j.1365-2745.2009.01633.x

Diaz S, Lavorel S, McIntyre S, et al. (2007) Plant trait responses to grazing - a global synthesis. Global Change Biol 13:313-341. doi.org/10.1111/j.1365-2486.2006.01288.x

Diez JM, Buckley HL, Case BS, et al. (2009) Interacting effects of management and environmental variability at multiple scales on invasive species distributions. J Appl Ecol 46:1210-1218. doi.org/10.1111/j.1365-2664.2009.01725.x

Dodd M, Barker G, Burns B, et al. (2011) Resilience of New Zealand indigenous forest fragments to impacts of livestock and pest mammals. NZ J Ecol 35:83-95

Dungan RJ, O'Cain MJ, Lopez ML, et al. (2002) Contribution by possums to seed rain and subsequent seed germination in successional vegetation, Canterbury, New Zealand. NZ J Ecol 26:121-128 
Elmhagen B, Rushton SP (2007) Trophic control of mesopredators in terrestrial ecosystems: top-down or bottom-up? Ecol Lett 10:197-206. doi.org/10.1111/j.1461$\underline{0248.2006 .01010 . x}$

Fabian Y, Sandau N, Bruggisser OT, et al. (2012) Diversity protects plant communities against generalist molluscan herbivores. Ecol Evol 2: 2460-2473. doi.org/10.1002/ece3.359

Fensham R, Silcock J, Dwyer J (2011) Plant species richness responses to grazing protection and degradation history in a low productivity landscape. J Veg Sci 22:997-1008. doi.org/10.1111/j.1654-1103.2011.01305.x

Firn J, House APN, Buckley YM (2010) Alternative states models provide an effective framework for invasive species control and restoration of native communities. J Appl Ecol 47:96-105. doi.org/10.1111/j.1365-2664.2009.01741.x

Forsyth DM, Wilmshurst JM, Allen RB, et al. (2010) Impacts of introduced deer and extinct moa on New Zealand ecosystems. NZ J Ecol 34:48-65

Grosholz E (2010) Avoidance by grazers facilitates spread of an invasive hybrid plant. Ecol Lett 13:145-153. doi.org/10.1111/j.1461-0248.2009.01409.x

Grove PB, Mark AF, Dickinson KJM (2002) Vegetation monitoring of recently protected tussock grasslands in the southern South Island, New Zealand. J Roy Soc NZ 32:379414. doi.org/10.1080/03014223.2002.9517700

Haarmeyer DH, Schmiedel U, Dengler J, et al. (2010) How does grazing intensity affect different vegetation types in arid Succulent Karoo, South Africa? Implications for conservation management. Biol Conserv 143:588-596. doi.org/10.1016/j.biocon.2009.11.008

Harris W, Fan J (1996) The role of fertiliser in the invasion of South Island high country by hawkweeds. Proc NZ Grassl Assoc 58:205-210

Hurst JM, Allen RB (2007) The Recce method for describing New Zealand vegetation - field protocols. Manaaki Whenua - Landcare Research, Lincoln, New Zealand 
Innes J, Hay R, Flux I, et al. (1999) Successful recovery of North Island kokako Callaeas cinerea wilsoni populations, by adaptive management. Biol Conserv 87:201-214. doi.org/10.1016/S0006-3207(98)00053-6

Jones C, Sanders MD (2005) European hedgehog. In: King CM (ed) The handbook of New Zealand Mammals, 2nd edn, Oxford University Press, Melbourne, Australia. pp 81-94

Kenkel NC, Orloci L (1986) Applying metric and nonmetric multidimensional scaling to ecological studies: some new results. Ecology 67:919-928. doi.org/10.2307/1939814

Kimball S, Schiffman PM (2003) Differing effects of cattle grazing on native and alien plants. Conserv Biol 17:1681-1693. doi.org/10.1111/j.1523-1739.2003.00205.x

King CM, Edgar RL (1977) Techniques for trapping and tracking stoats (Mustela erminea): a review, and a new system. NZ J Zool 4:193-212. doi.org/10.1080/03014223.1977.9517953

Kutt AS, Gordon IJ (2012) Variation in terrestrial mammal abundance on pastoral and conservation land tenures in north-eastern Australian tropical savannas. Anim Conserv 15:416-425. doi.org/10.1111/j.1469-1795.2012.00530.x

Lee W, Wood J, Rogers G (2010) Legacy of avian-dominated plant-herbivore systems in New Zealand. NZ J Ecol 34:28-47

Legge S, Kennedy MS, Lloyd R, et al. (2011) Rapid recovery of mammal fauna in the central Kimberley, northern Australia, following removal of introduced herbivores. Aust Ecol 36:791-799. doi.org/10.1111/j.1442-9993.2010.02218.x

Lunt I, Eldridge D, Morgan J, et al. (2007) A framework to predict the effects of livestock grazing and grazing exclusion on conservation values in natural ecosystems in Australia. Aust J Bot 55:401-415. doi.org/10.1071/BT06178

Mack RN, Simberloff D, Lonsdale WM, et al. (2000) Biotic invasions: causes, epidemiology, global consequences, and control. Ecol Appl 10:689-710. doi.org/10.1890/10510761(2000)010[0689:BICEGC]2.0.CO;2

MacKay AD, Lambert MG (2011) Long-term changes in soil fertility and pasture production under no, low and high phosporous fertiliser inputs. Proc NZ Grassl Assoc 73:37-42 
Mark AF (1969) Ecology of snow tussocks in the mountain grasslands of New Zealand. Vegetatio 18:289-306. doi.org/10.1007/BF00332843

Mark AF, Dickinson KJM (2003) Temporal responses over 30 years to removal of grazing from a mid-altitude snow tussock grassland reserve, Lammerlaw Ecological Region, New Zealand. NZ J Bot 41:655-667. doi.org/10.1080/0028825X.2003.9512876

May F, Grimm V, Jeltsch F (2009) Reversed effects of grazing on plant diversity: the role of below-ground competition and size symmetry. Oikos 118:1830-1843. doi.org/10.1111/j.1600-0706.2009.17724.x

McGlone MS, Wilmshurst JM (1999) Dating initial Maori environmental impact in New Zealand. Quat Int 59:5-16. doi.org/10.1016/S1040-6182(98)00067-6

Meffin R, Miller AL, Hulme PE, et al. (2010) Experimental introduction of the alien plant Hieracium lepidulum reveals no significant impact on montane plant communities in New Zealand. Divers Distrib 16:804-815. doi.org/10.1111/j.1472-4642.2010.00684.x

Meurk CD, Walker S, Gibson RS, et al. (2002) Changes in vegetation states in grazed and ungrazed Mackenzie Basin grasslands, New Zealand, 1990-2000. NZ J Ecol 26:95-106

Norbury G, Flux JEC (2005) Brown hare. In: King CM (ed) The handbook of New Zealand mammals, 2nd edn, Oxford University Press, Melbourne, Australia, pp 151-158

Norbury G, Reddiex B (2005) European rabbit. In: King CM (ed) The handbook of New Zealand mammals, 2nd edn, Oxford University Press, Melbourne, Australia, pp 131151

Norbury GL, Byrom AE, Pech RP, et al. (2013) Invasive mammals and habitat modification interact to generate unforeseen outcomes for indigenous fauna. Ecol Appl doi.org/10.1890/12-1958.1

Norton DA, Espie PR, Murray W, et al. (2006) Influence of pastoral management on plant biodiversity in a depleted short tussock grassland, Mackenzie Basin. NZ J Ecol 30:335344

O’Hara R, Kotze J (2010) Do not log-transform count data. Methods Ecol Evol 1:118-122 
Oksanen J, Blanchet FG, Kindt R, et al. (2010) Vegan: Community ecology package. R package version 1.17-1.

Partridge T, Allen R, Johnson P, et al. (1991) Vegetation/environment relationships in lowland and montane vegetation of the Kawarau Gorge, Central Otago, New Zealand. NZ J Bot 29:295-310. doi.org/10.1080/0028825X.1991.10416608

R Development Core Team (2009) R: a language and environment for statistical computing. Version 2.10.1. R Foundation for Statistical Computing, Vienna, Austria

Rogers G, Walker S, Lee B (2005) The role of disturbance in dryland New Zealand: past and present. Science for Conservation 258, Department of Conservation, Wellington, New Zea;and, pp 1-122

Rose AB, Frampton CM (2007) Rapid short-tussock grassland decline with and without grazing, Marlborough, New Zealand. NZ J Ecol 31:232-244

Rose AB, Platt KH (1992) Snow tussock (Chionochloa) population responses to removal of sheep and European hares, Canterbury, New Zealand. NZ J Bot 30:373-382. doi.org/10.1080/0028825X.1992.10412917

Rose AB, Platt KH, Frampton CM (1995) Vegetation change over 25 years in a New Zealand short-tussock grassland: effects of sheep grazing and exotic invasions. NZ J Ecol 19:163-174

Rose AB, Suisted PA, Frampton CM (2004) Recovery, invasion, and decline over 37 years in a Marlborough short-tussock grassland, New Zealand. NZ J Bot 42:77-87. doi.org/10.1080/0028825X.2004.9512891

Sage DJM, Norton DA, Espie PR (2009) Effect of grazing exclusion on the woody weed Rosa rubiginosa in high country short tussock grasslands. NZ J Agric Res 52:123-128. doi.org/10.1080/00288230909510496

Scherber C, Eisenhauer N, Weisser WW, et al. (2010a) Bottom-up effects of plant diversity on multitrophic interactions in a biodiversity experiment. Nature 468:553-556. doi.org/10.1038/nature09492 
Scherber C, Heimann J, Kohler G, et al. (2010b) Functional identity versus species richness: herbivory resistance in plant communities. Oecologia 163:707-717. doi.org/10.1007/s00442-010-1625-1

Schielzeth H (2010) Simple means to improve the interpretability of regression coefficients. Methods Ecol Evol 1:103-113. doi.org/10.1111/j.2041-210X.2010.00012.x

Scott NA, Saggar S, McIntosh PD (2001) Biogeochemical impact of Hieracium invasion in New Zealand's grazed tussock grasslands: Sustainability implications. Ecol Appl 11:1311-1322. doi.org/10.1890/1051-0761(2001)011[1311:BIOHII]2.0.CO;2

Skaer MJ, Graydon DJ, Cushman JH (2013) Community-level consequences of cattle grazing for an invaded grassland: variable responses of native and exotic vegetation. J Veg Sci 24:332-343. doi.org/10.1111/j.1654-1103.2012.01460.x

Smit R, Bokdam J, den Ouden J, et al. (2001) Effects of introduction and exclusion of large herbivores on small rodent communities. Plant Ecol 155:119-127

Souter NJ, Milne T (2009) Grazing exclusion as a conservation measure in a South Australian temperate native grassland. Grassl Sci 55:79-88

Sweetapple P, Nugent G (2011) Chew-track-cards: a multiple-species small mammal detection device. NZ J Ecol 35:153-162

Tate KR, Scott NA, Saggar S, et al. (2003) Land-use change alters New Zealand's terrestrial carbon budget: uncertainties associated with estimates of soil carbon change between 1990-2000. Tellus B 55:364-377. doi.org/10.1034/j.1600-0889.2003.01444.x

Thorsen MJ, Dickinson KJM, Seddon PJ (2009) Seed dispersal systems in the New Zealand flora. Perspect Plant Ecol, Evol Syst 11:285-309. doi.org/10.1016/j.ppees.2009.06.001

Verhoeven KJF, Simonsen KL, McIntyre LM (2005) Implementing false discovery rate control: increasing your power. Oikos 108: 643-647. doi.org/10.1111/j.0030$\underline{1299.2005 .13727 . \mathrm{x}}$

Verrier FJ, Kirkpatrick JB (2005) Frequent mowing is better than grazing for the conservation value of lowland tussock grasssland at Pontville, Tasmania. Aust Ecol 30:74-78. doi.org/10.1111/j.1442-9993.2004.01425.x 
Virgós E, Cabezas-Díaz S, Malo A, et al. (2003) Factors shaping European rabbit abundance. Acta Theriol 48:113-122. doi.org/10.1007/BF03194271

Walker S (2000) Post-pastoral changes in composition and guilds in a semi-arid conservation area, Central Otago, New Zealand. NZ J Ecol 24:123-137

Walker S, Lee WG (2002) Alluvial grasslands of Canterbury and Marlborough, eastern South Island, New Zealand: vegetation patterns and long-term change. J Roy Soc NZ 32:113147. doi.org/10.1080/03014223.2002.9517686

Walker S, Wilson JB, Lee WG (2003) Recovery of short tussock and woody species guilds in ungrazed Festuca novae-zelandiae short tussock grassland with fertiliser or irrigation. NZ J Ecol 27:179-189

Walker S, Wilson JB, Lee WG (2005) Does fluctuating resource availability increase invasibility? Evidence from field experiments in New Zealand short tussock grassland. Biol Invas 7:195-211. doi.org/10.1007/s10530-004-8976-7

Walker S, Price R, Stephens RT (2008) An index of risk as a measure of biodiversity conservation achieved through land reform. Conserv Biol 22:48-59. doi.org/10.1111/j.1523-1739.2007.00844.X

Walker S, Cieraad E, Monks A, et al. (2009) Long-term dynamics and rehabilitation of woody ecosystems in dryland South Island, New Zealand. In: Hobbs RJ and Suding KN (eds) New models for ecosystem dynamics and restoration. Island Press, Washington, DC, pp 99-111.

Warburton B (2005) Bennett's wallaby. In: King CM (ed) The handbook of New Zealand mammals, 2nd edn, Oxford University Press, Melbourne, Australia, pp 39-45

Weigelt A, Schumacher J, Walther T, et al. (2007) Identifying mechanisms of competition in multi-species communities. J Ecol 95:53-64. doi.org/10.1111/j.13652745.2006.01198.x

Williams PA, Karl BJ, Bannister P, et al. (2000) Small mammals as potential seed dispersers in New Zealand. Aust Ecol 25:523-532. doi.org/10.1046/j.14429993.2000.01078.x 
Wilson DJ, Lee WG (2010) Primary and secondary resource pulses in an alpine ecosystem: snow tussock grass (Chionochloa spp.) flowering and house mouse (Mus musculus) populations in New Zealand. Wildl Res 37:89-103. doi.org/10.1071/WR09118

Yeaton RI, Flores JLF (2009) Community structure of a southern Chihuahuan Desert grassland under different grazing pressures. S Afr J Bot 75:510-517. doi.org/10.1016/j.sajb.2009.04.004

Young LM (2012) Seed dispersal mutualisms and plant regeneration in New Zealand alpine ecosystems. PhD thesis, School of Biological Sciences, University of Canterbury, New Zealand. $182 \mathrm{p}$ 
Table 1 Study sites: locations ( $\mathrm{L} / \mathrm{L}=$ Latitude/Longitude), rainfall (R), history of grazing and disturbance (exotic plant removal, fertilisation and burning), and dominant vegetation. General descriptions of the presence and cover of vascular plant species were based on the Recce method (Hurst and Allen 2007), modified to include the entire site. Further details are available in Online Resource 1

\begin{tabular}{|c|c|c|c|c|c|}
\hline Site & $L / L$ & $\mathbf{R}(\mathrm{mm})$ & $\begin{array}{l}\text { Time between } \\
\text { destocking and } \\
\text { our study } \\
\text { (years) }\end{array}$ & Prior disturbance & Dominant vegetation \\
\hline Boundary Hill & $\begin{array}{l}43.340^{\circ} \mathrm{S}, \\
171.631^{\circ} \mathrm{E}\end{array}$ & 870 & 17 & $\begin{array}{l}\text { No known exotic plant removal } \\
\text { or fertiliser application since } \\
\text { destocking. No history of } \\
\text { burning }\end{array}$ & $\begin{array}{l}\text { Regenerating shrubland dominated by inaka } \\
\text { (Dracophyllum longifolium), matagouri (Discaria } \\
\text { toumatou), kānuka (Kunzea ericoides), mixed with } \\
\text { native short-tussock species and exotic grasses }\end{array}$ \\
\hline Coach Stream & $\begin{array}{l}43.305^{\circ} \mathrm{S} \\
171.744^{\circ} \mathrm{E}\end{array}$ & 950 & 10 & $\begin{array}{l}\text { No exotic plant removal or } \\
\text { fertiliser application for }>30 \\
\text { years. Last known burn }>40 \\
\text { years ago }\end{array}$ & $\begin{array}{l}\text { Regenerating shrubland dominated by matagouri, } \\
\text { bracken (Pteridium esculentum), Coprosma } \\
\text { propinqua, Muehlenbeckia complexa, short-tussock } \\
\text { species and exotic grasses }\end{array}$ \\
\hline Freehold Creek & $\begin{array}{l}44.276^{\circ} \mathrm{S} \\
169.814^{\circ} \mathrm{E}\end{array}$ & 840 & 27 & $\begin{array}{l}\text { No exotic plant removal. } \\
\text { Fertiliser application on grazed } \\
\text { side of fence } 20 \text { years ago, and } \\
\text { twice subsequently. No history }\end{array}$ & $\begin{array}{l}\text { Regenerating shrubland dominated by mānuka } \\
\text { (Leptospermum scoparium), matagouri, sweet briar } \\
\text { (Rosa rubiginosa) and mixed exotic/native grassland }\end{array}$ \\
\hline
\end{tabular}


of burning

Mount Nimrod $44.43^{\circ} \mathrm{S}, \quad 800 \quad 35$

$170.86^{\circ} \mathrm{E}$
Spot removal of woody exotics

(gorse), burning (ceased > 15

years ago), and aerial

application of fertiliser every 3

years (all on grazed side of

fence only)
Native shrubland dominated by broadleaf (Griselinia

littoralis) and bracken, native forest regenerating in gullies and mixed exotic/native grassland 
Table 2 Comparison of vegetation characteristics of sites under pastoral and conservation tenure in grass/shrubland communities. Plants $<0.3 \mathrm{~m}$ high were defined as ground species. Mean ( \pm se) species richness (species per $0.25 \mathrm{~m}^{2}$ ) and cover $(\%)$ were calculated from mean plot measures per site. Significance was assessed by a one-way ANOVA, including site as a random factor. Asterisks represent significant differences between pastoral and conservation tenure after controlling for multiple tests using the false discovery rate procedure (Verhoeven et al. 2005).

\begin{tabular}{lll}
\hline & Pastoral & Conservation \\
\hline Richness & & \\
Total richness & $10.52 \pm 0.14$ & $10.90 \pm 0.18$ \\
Total native richness* & $5.04 \pm 0.15$ & $7.73 \pm 0.14$ \\
Total exotic richness* & $5.48 \pm 0.10$ & $3.17 \pm 0.08$ \\
Total ground richness & $10.84 \pm 0.14$ & $11.19 \pm 0.19$ \\
Native ground richness & $5.47 \pm 0.15$ & $8.08 \pm 0.15$ \\
Exotic ground richness* & $5.37 \pm 0.09$ & $3.11 \pm 0.08$ \\
Total shrub richness & $0.59 \pm 0.04$ & $1.08 \pm 0.05$ \\
Native shrub richness & $0.52 \pm 0.03$ & $1.06 \pm 0.05$ \\
Exotic shrub richness & $0.07 \pm 0.01$ & $0.02 \pm 0.01$ \\
Tussock richness & $0.65 \pm 0.03$ & $0.74 \pm 0.03$ \\
Hawkweed richness & $0.93 \pm 0.04$ & $1.04 \pm 0.04$ \\
Exotic grass richness* & $2.64 \pm 0.05$ & $1.56 \pm 0.05$ \\
& & \\
Cover & & \\
Total shrub cover & $9.56 \pm 0.77$ & $23.95 \pm 1.37$ \\
Native shrub cover & $8.85 \pm 0.75$ & $23.76 \pm 1.36$ \\
Exotic shrub cover & $0.71 \pm 0.14$ & $0.37 \pm 0.19$ \\
Tussock cover & $7.93 \pm 0.61$ & $9.83 \pm 0.77$ \\
Hawkweed cover & $18.48 \pm 0.96$ & $20.27 \pm 0.97$ \\
Exotic grass cover & $51.73 \pm 1.43$ & $26.70 \pm 1.19$ \\
Bare ground cover & $1.09 \pm 0.26$ & $0.33 \pm 0.09$ \\
Litter cover & $0.69 \pm 0.28$ & $0.78 \pm 0.58$ \\
Rock cover & $3.32 \pm 1.98$ & $5.76 \pm 2.66$ \\
\hline & & \\
\hline
\end{tabular}




\section{Figure captions}

Fig. 1 Schematic layout of the sampling grids showing relative locations of, rodent stations, tracking tunnels, chew cards and pellet count lines, with vegetation quadrats located at each grid intersection. Pellet count lines have been offset from the sampling grid for ease of interpretation. Inset shows the location of the four sampling areas within the South Island, New Zealand. Areas are labelled as follows: B - Boundary Hill, C - Coach Stream, F Freehold Creek, N - Mount Nimrod. See Methods for details of the sampling design

Fig. 2 Differences in mammal and vegetation communities at sites under pastoral and conservation tenure. Plots represent the results of non-metric multidimensional scaling analyses, for differences in the introduced mammal community by (a) species and (b) site, and (c) for the vegetation community by site. White circles represent pastoral sites, while black circles represent conservation sites. Sites are labelled by area: B - Boundary Hill (2 pairs of sites), C - Coach Stream (1 pair), F - Freehold Creek (3 pairs), N - Mount Nimrod (2 pairs). Stress values: invasive mammal community -0.13 ; vegetation community -0.10

Fig. 3 Mean effect sizes of plot-level predictors on (a) total species richness of native plants, and (b) richness of native ground plants ( $<0.3 \mathrm{~m}$ high), under pastoral (white) and conservation tenure (black). Effect sizes were calculated using a mixed effects model, with points representing mean regression coefficients $( \pm \mathrm{SE})$ 
Fig. 1
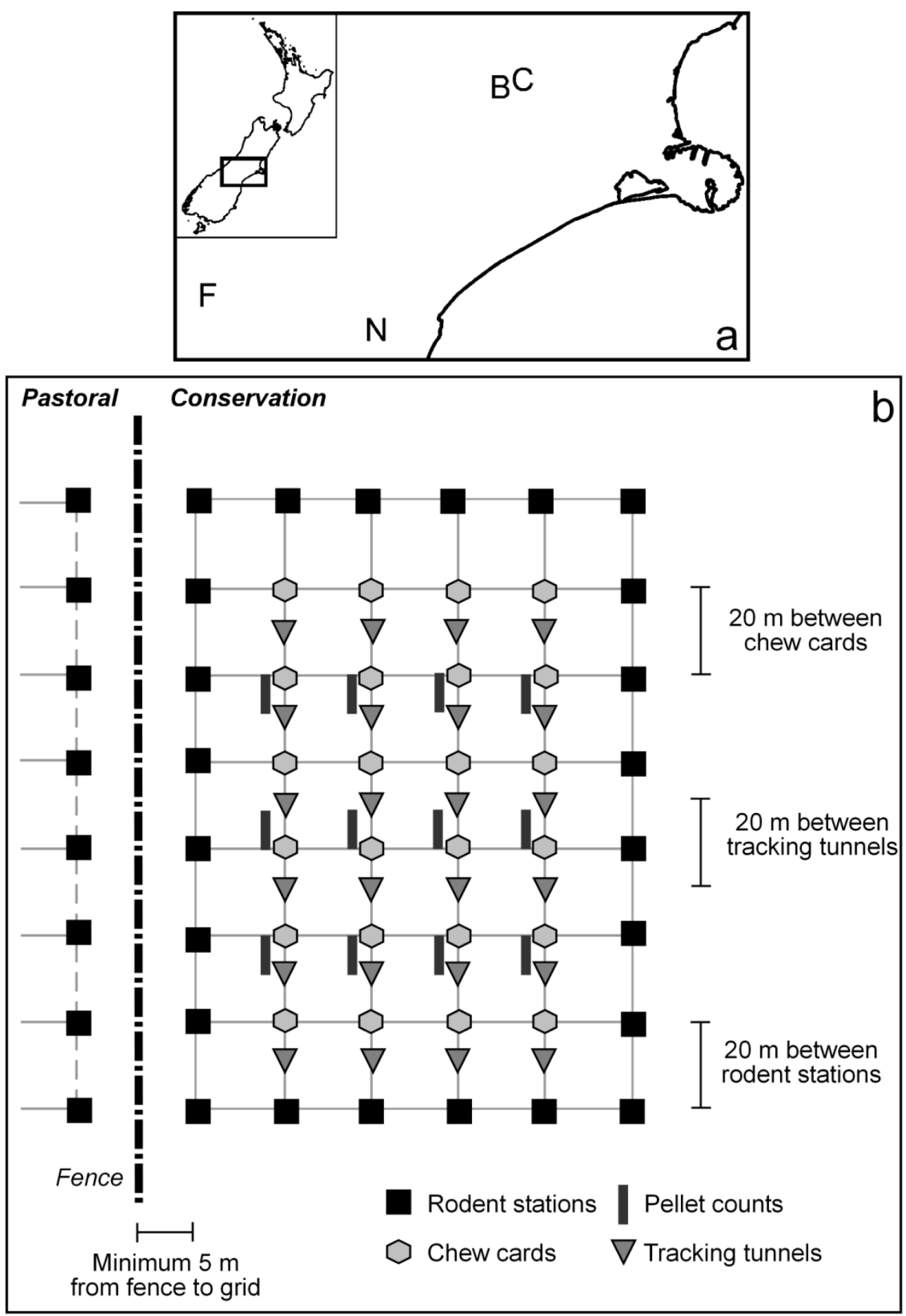
Fig. 2
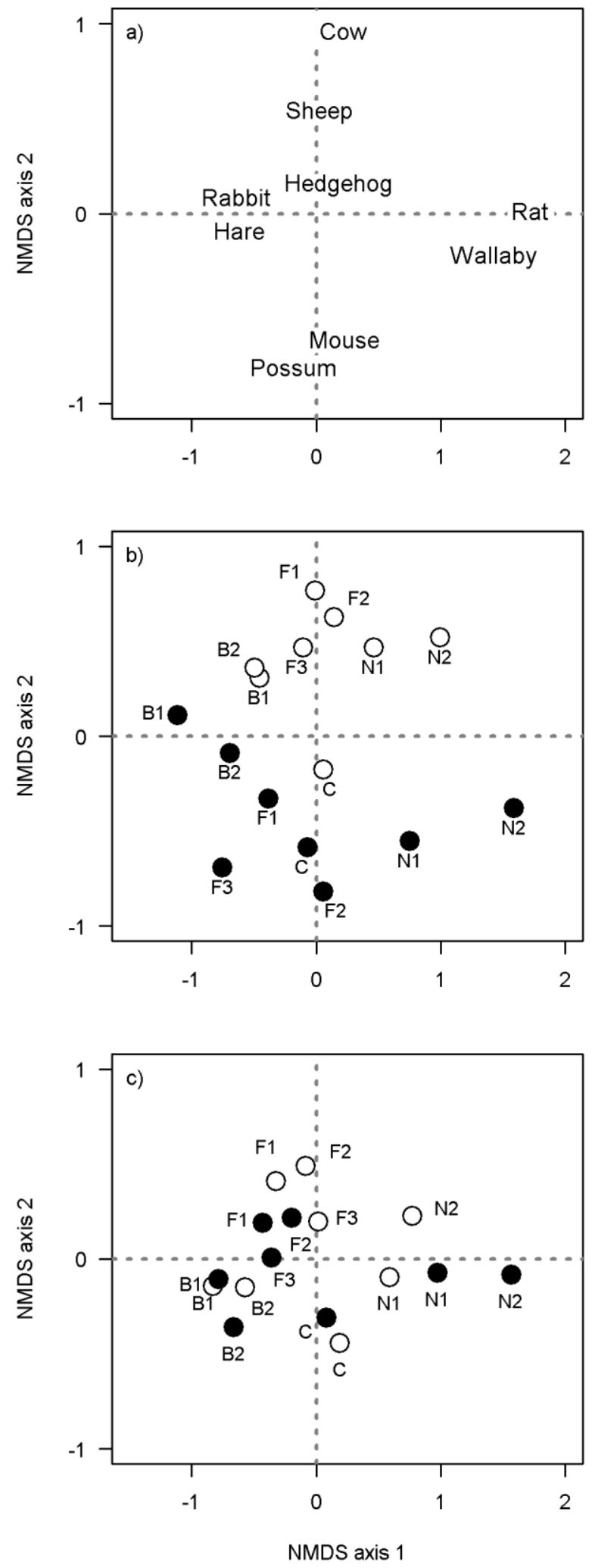
Fig. 3

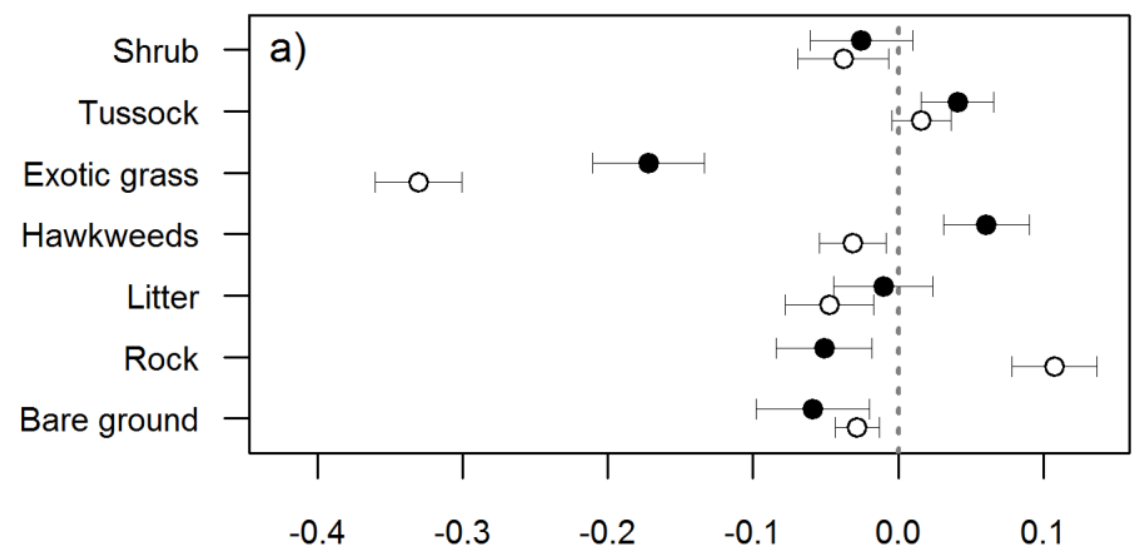

Effect on total native richness

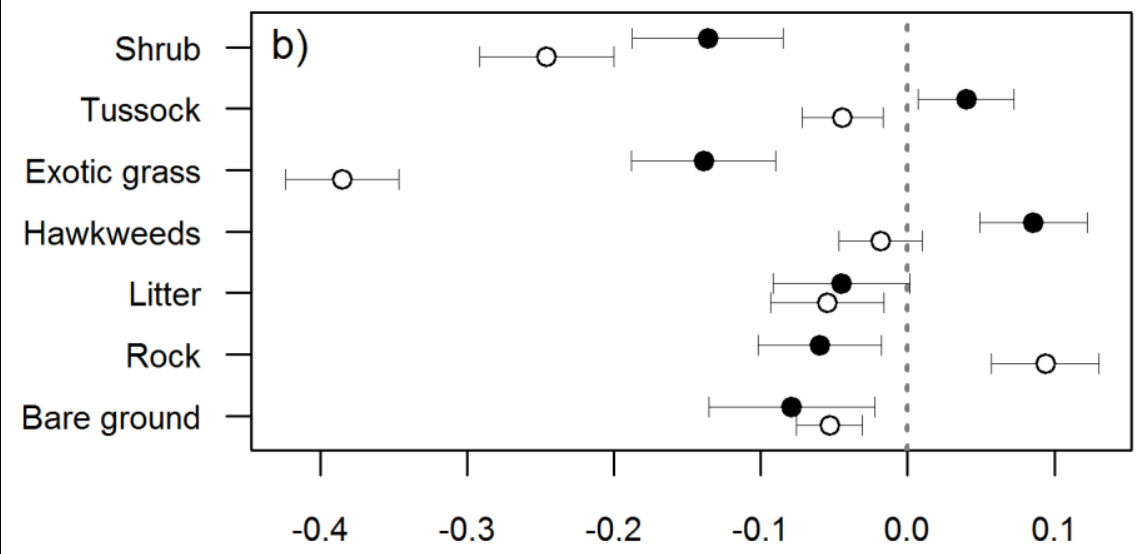

Effect on native ground richness 

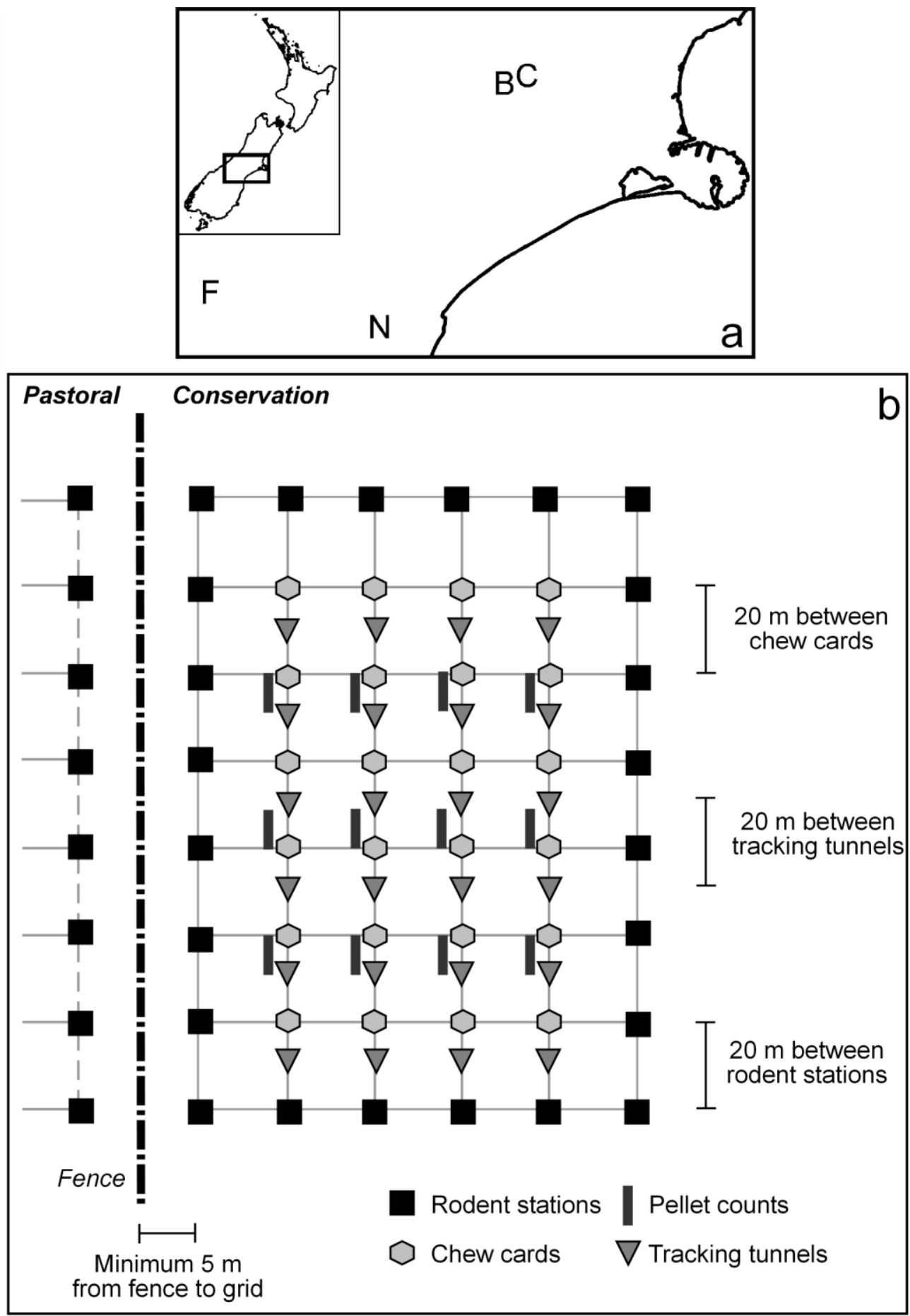

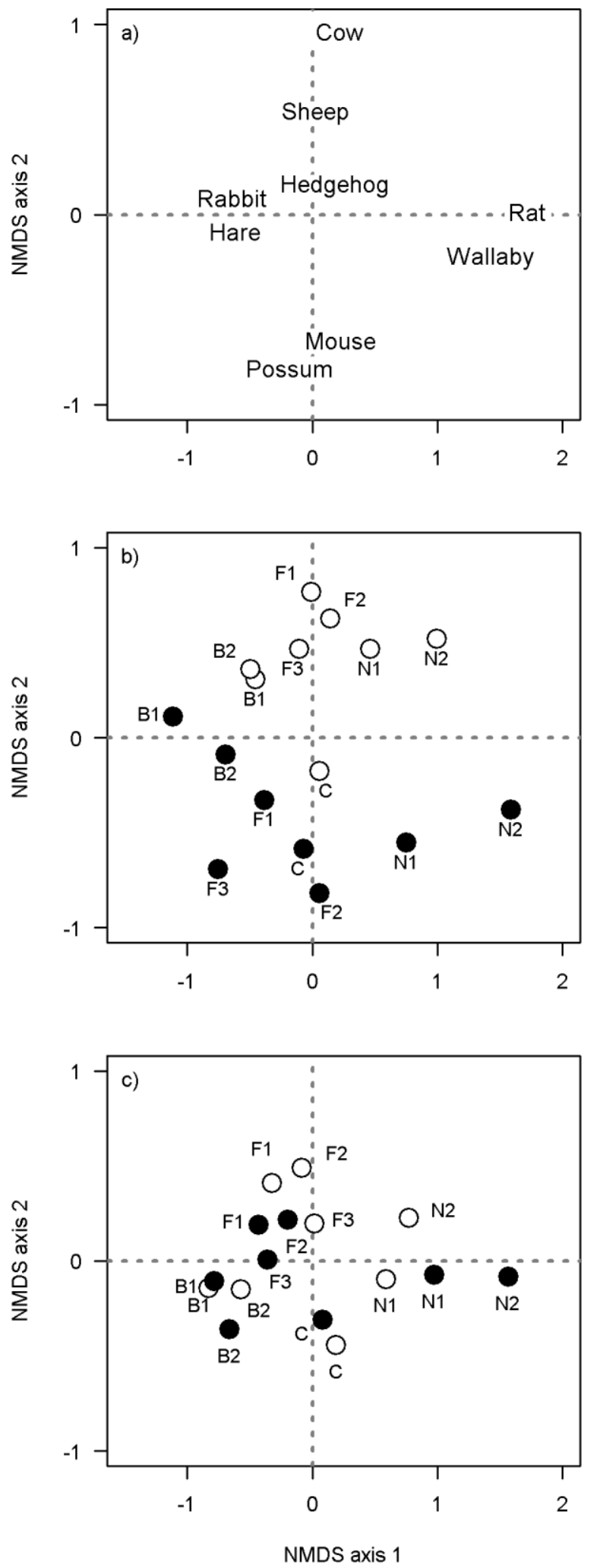


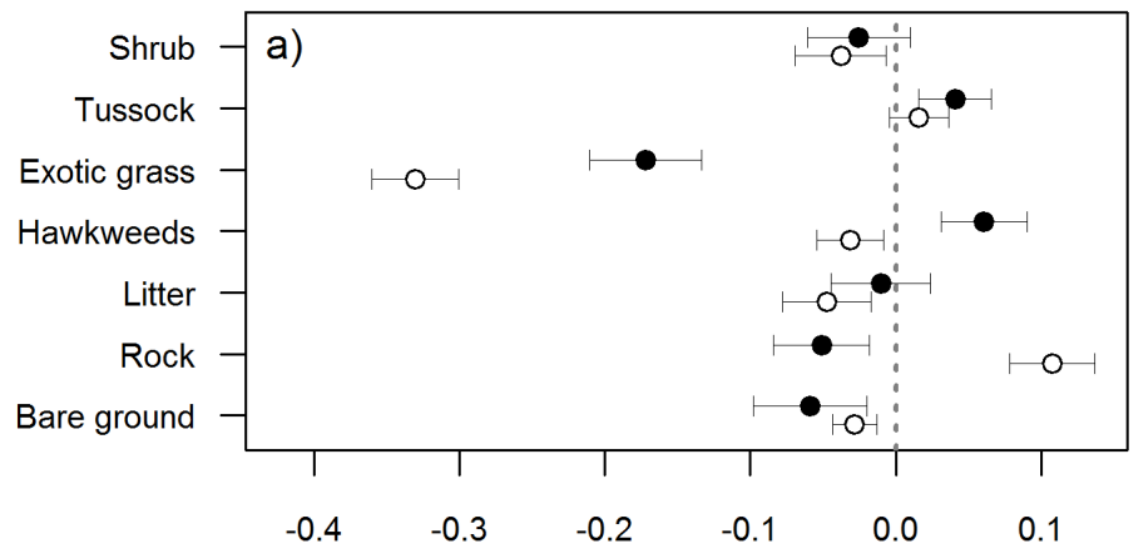

Effect on total native richness

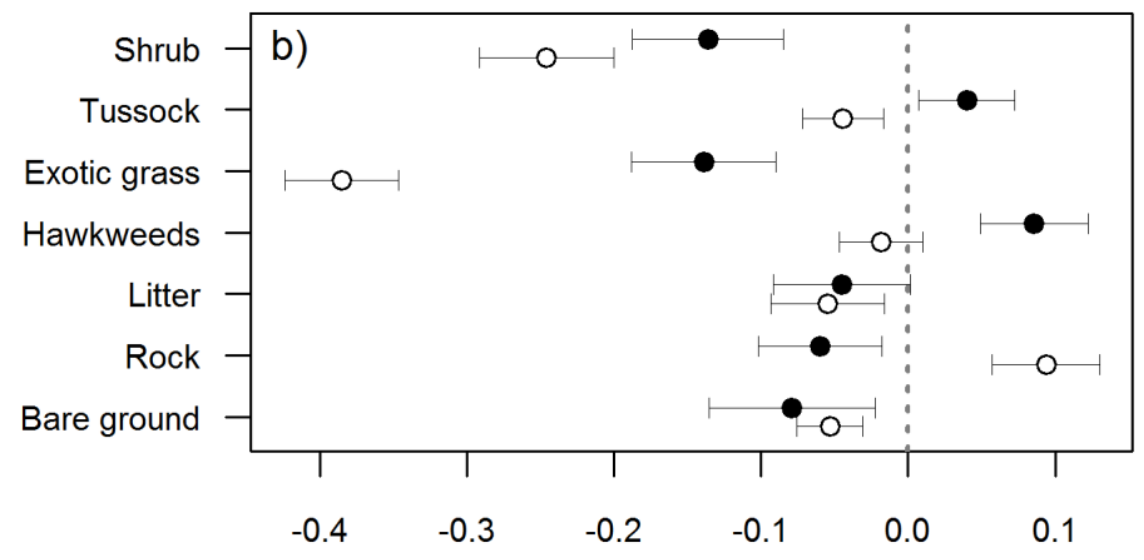

Effect on native ground richness 


\section{University Library}

\section{- M M I N E R VA \\ A gateway to Melbourne's research publications}

Minerva Access is the Institutional Repository of The University of Melbourne

Author/s:

Whitehead, AL;Byrom, AE;Clayton, Rl;Pech, RP

Title:

Removal of livestock alters native plant and invasive mammal communities in a dry grassland-shrubland ecosystem

Date:

2014-01-01

Citation:

Whitehead, A. L., Byrom, A. E., Clayton, R. I. \& Pech, R. P. (2014). Removal of livestock alters native plant and invasive mammal communities in a dry grassland-shrubland ecosystem. Biological Invasions, 16 (5), pp.1105-1118. https://doi.org/10.1007/ s10530-013-0565-1.

Persistent Link:

http://hdl.handle.net/11343/282757 